\title{
ACRL Nominees for Offices, 1976/77
}

\section{VICE-PRESIDENT/PRESIDENT-ELECT}

Johnnie E. Givens, Librarian, Austin Peay State University, Clarksville, TN 37040

Eldred E. Smith, Director of Libraries, State University of New York at Buffalo, Buffalo, NY 14214

\section{DIRECTORS-AT-LARGE}

Pauline Atherton, Professor, School of Information Studies, Syracuse University, Syracuse, NY 10310

Jane G, Flener, Associate University Librarian, University of Califomia, Berkeley, CA 94720

Louis C. Moloney, Head Librarian, Southwest Texas State University, San Marcos, TX 78666

Thomas E. Strader, Director, Towson State College, Baltimore, MD 21204

\section{AGRICULTURE AND BIOLOGICAL SCIENCES SECTION}

Vice-Chairman/Chairman-Elect

Doris Bolef, Assistant Dean for Learning Resources, College of Medicine, East Tennessee State University, Johnson City, TN 37601

Nancy F. Hardy, Instructor, School of Library and Information Science, University of Missouri-Columbia, Columbia, MO 6520I Secretary

Teresa M. Libro, Biomedical Librarian, Wausau Hospital North, Wausau, WI 54401

Linnea A. Sodergren, Regional Services Coordinator, The John Crerar Library, Chicago, IL 60616

\section{ANTHROPOLOGY SECTION}

Vice-Chairman/Chairman-Elect

Anne K. Beaubien, Social Science Reference Librarian, University of Michigan Library, Ann Arbor, MI 48104

Marilyn L. Haas, Reference Librarian, Lockwood Memorial Library, State University of New York at Buffalo, Buffalo, NY 14214

Member-at-Large

Hazel M. Johnson, Social Science Bibliographer, Hillman Library, University of Pittsburgh, Pittsburgh, PA 15260

Max L. Plaut, Reference Librarian, Field Museum of Natural History, Chicago, IL 60605

\section{ART SECTION}

Vice-Chairman/Chairman-Elect

Jean L. Finch, Library Director, Art Institute of Chicago, Chicago, IL 60603

Antje B. Lemke, Professor, School of Infor- mation Studies, Syracuse University, Syracuse, NY 13210

\section{ASIAN AND AFRICAN SECTION}

Vice-Chairman/Chairman-Elect

To be nominated

Secretary

To be nominated

Member-at-Large

To be nominated

\section{COLLEGE LIBRARIES SECTION}

Vice-Chairman/Chairman-Elect

Mary Louise B. Cobb, Head, Cataloging Department, College of William and Mary, Williamsburg, VA 23185

Betty-Carol Sellen, Chief, Circulation Division, Brooklyn College Library, Brooklyn, NY 11210

Secretary

Robert K. Bruce, Reader Services Librarian and Acting Librarian, University of AlaskaSoutheast, Juneau, AL 99801

Barbara J. Williams, Head Librarian, South Carolina State College, Orangeburg, SC 29117

\section{COMMUNITY AND JUNIOR COLLEGE LIBRARIES SECTION}

Vice-Chairman/Chairman-Elect

Sidney August, Director, Division of Educational Resources, Community College of Philadelphia, Philadelphia, PA 19107

One to be nominated

Secretary

Joseph F. Lindenfeld, Director of Library Services, Shelby State Community College, Memphis, TN 38104

Kathlyn King Lundgren, Audiovisual Librarian, Nebraska Western College, Scottsbluff, NE 69361

\section{EDUCATION AND BEHAVIORAL SCIENCES SECTION}

Vice-Chairman/Chairman-Elect

Joe Mapes, Education Librarian, University of Colorado, Boulder, CO 80302

Lawrence W. Marble, Director of Libraries, Lesley College, Cambridge, MA 02138

\section{LAW AND POLITICAL SCIENCE SECTION}

Vice-Chairman/Chairman-Elect

Signe M. Larson, Chief, Research Services, U.S. Department of the Interior Library, Washington, DC 20240

Egon Weiss, Librarian, U.S. Military Academy, West Point, NY 10996 


\section{Three timely reports onl librury systems from"the authority"}

\section{Automated Circulation Control Systems: An Overview of Com- mercially Vended Systems}

An extensive discussion by Barbara Evans Markuson of the characteristics of five circulation control systems, including CLSI, Checkpoint/Plessey, and Check-A-Book. In the July \& September 1975 issues of LTR. $\$ 35$.

\section{Microform Catalog Data Retrieval Systems}

A comparison of Information Design, Information Dynamics, and Library Processing Systems. In the May 1975 issue of $L T R$. $\$ 20$.

\section{Theft Detection Systems for Libraries}

A revealing and valuable 98 -page survey of manufacturers and users. In the May 1974 Issue of LTR. $\$ \mathbf{2 0}$.

\section{Library Technology Reports (LTR)}

is a unique bimonthly publication of the American Library Association that provides critical evaluations of products used in libraries, media centers, schools, and other educational institutions. Its purpose is twofold: to enable librarians and educators to make economical purchase decisions and to alert manufacturers of library needs and standards of performance expected.

To order any of the above individual issues or for additional information on the complete subscription service, write to:

\section{LIBRARY TECHNOLOGY REPORTS} American Library Association 50 East Huron Street Chicago, Illinois 60611
Secretary

Marie Morris, Reference Librarian, Emory

University, Atlanta, GA 30322

One to be nominated

Member-at-Large

Alice Dulaney Ball, Executive Director, United States Book Exchange, Washington, DC 20018

Aaron Hause, Documents Librarian, Hofstra University, Hempstead, NY 11550

\section{RARE BOOKS AND MANUSCRIPTS SECTION}

Vice-Chairman/Chairman-Elect

Terry Belanger, Assistant Professor, School of Library Service, Columbia University, New York, NY 10027

Marian Orgain, Curator, Special Collections, University of Houston, Houston, TX 77004

Member-at-Large

Anne C. Skoog, Fine and Rare Books Librarian, Carnegie-Mellon University, Pittsburgh, PA 15213

William P. Wreden, William P. Wreden Books \& Manuscripts, Palo Alto, CA 94302

\section{SLAVIC AND EAST EUROPEAN SECTION}

Vice-Chairman/Chairman-Elect

Eugene E. Petriwsky, University of Colorado Libraries, Boulder, CO 80302

David P. Rose, Slavic Bibliographer, University of North Carolina Library, Chapel Hill, N.C.

Member-at-Large

Marvin F. Bielawski, Cataloger, Princeton University Library, Princeton, N.J.

Carol A. Leadenham, Cataloger, University of Arizona Library, Tucson, Ariz.

\section{UNIVERSITY LIBRARIES SECTION}

Vice-Chairman/Chairman-Elect

Millicent D. Abell, Associate Director of Libraries, State University of New York at Buffalo, Buffalo, NY 14214

Susan S. Brynteson, Associate Director for Technical Services, University of Tennessee Libraries, Knoxville, TN 37916

Secretary

E. J. Josey, Chief, Bureau of Academic and Research Libraries, New York State Education Department, Albany, NY 12210

John Lubans, Jr., Assistant Director for Public Services, University of Colorado, Boulder, CO 80302

For out-of-print issues of College b Research Libraries News, write to University Microfilms, 300 North Zeeb Rd., Ann Arbor, MI 48106. Issues are available one year after date of publication. 